\title{
Women Education: A Means for Curbing Women Trafficking
}

\author{
Dije Musa Gumel
}

\author{
Department of Early Child Care and Education,Federal College of Education, Kano-Nigeria
}

\section{Doi:10.5901/mjss.2014.v5n26p75}

\section{Abstract}

As the saying goes: "to educate a woman is to educate a nation "; hence, women's education should not be underscored. No nation on earth will progress without educating its women. This paper highlights the concept of education, women's education, human trafficking as well as the objectives of women's education. In the introduction, the paper discusses the importance of women as home keepers and bearers of children. It also discusses on the menace of human trafficking and its implications to the life of women in every nation. Conclusion and recommendations were also made. Some of the recommendations are: to curb women trafficking, education for the girl-child must be reinvigorated. Government should find the reasons that push women towards this problem of trafficking and provide solutions.

\section{Introduction}

Women education has a great role to play in the development of a nation. It is perhaps the most fundamental instrument for development in every society. In Nigeria, the traditional women play the role of home keepers, bearing and rearing children and they are also responsible for training and producing welfare for the family.

In every culture, women stand out as active participants in the provision of family welfare. The Nigerian women have proven to be industrious, self-asserting when it comes to the issue of their family well-being. It is a proven fact that during conflicts, women face gross violation of human rights, particularly gender based violence such as gang rape, sexual slavery and torture (Ander, 2003).

Thus, most international institutions as well as individual governments worldwide have embarked on campaigns to improve women enrollment in formal education.

Moreover, education for women is a development priority due to the dynamic potential of educated women (Adamu, 1996).

\section{Concept of Education}

Education in its broadest sense, is the means through which the aims and habits of a group of people is sustained from one generation to the next.

Taylor (2007) perceives Education as "the transmission of culture which includes knowledge, belief, arts, morals, laws, customs and any other capability acquired by man as a member of the society". Education plays an indispensable role in individual, regional, national and global development. Therefore, education is a major enterprise/aspect a country like Nigeria should invest in.

Education is a fundamental instrument which differentiates a fully developed human being from other mammals. It is the criterion for measuring the mental, spiritual, political, and to some extent, the material development of man (Aliyu, 2004). Education is therefore, a necessary ingredient for a meaningful development for a man and woman as well as their society. Education, in other words, is the key to success of mankind. Whoever wants to operate a happy and successful life in this world of materialism should seek for education. Lazure (1996) states that for the life of mankind to be meaningful, purposeful goal-oriented, as well as living in peace and tranquility, and achieve societal concord, men and women must acquire a qualitative, functional, goal-oriented, useful, positively beneficial, and goal-oriented education. He further stated that, education is the basis, the invariable index for the socio-political, economic, physical, moral, spiritual, scientific and technological development of man and his society. 


\section{Concept of Women Education}

According to Surra (1996), education is a potential ingredient for changing a woman's life.

Allele (1994) believes that women education is that type of education received by women that would make them to become aware of themselves and their capacity to exploit the environment. Women education is therefore, seen as a process whereby women are given equal opportunities to knowledge, skills, job participation in the wider society which help in nation building and better society. This type of education involves training in literacy and vocational skills to enable them become functional in their society, especially their homes. Education will help the women to be aware of their rights and ways to do things.

\section{Concept of Human Trafficking}

Human trafficking is a serious crime and grave violation of human rights. Every year, thousands of men, women and children fall into the hands of traffickers in their own countries and abroad. Almost every country in the world is affected by trafficking, whether as a country of origin, transit or destination for victims.

Ibrahim (2002) presented human trafficking as the recruitment, transportation, transfer, harbouring or receipt of persons by means of threat or use of force or coercion, of abduction of fraud vulnerability or the consent of a person having control over another person for the purpose of exploitation.

Adedokun (2008) defined human trafficking as an illegal or immoral trading which involves slaves or human beings for the purpose of material gain.

United Nations Office on Drug and Crimes (UNODC) defines human trafficking as trafficking in persons as the recruitment, transportation, transfer, harboring or receipt of persons, by means of threat or use of force or other forms of coercion, of abduction of fraud, deception of the abuse of power or of a position of vulnerability or of the giving or receiving of payments or benefits to achieve the consent of a person for the purpose of exploitation. These exploitation shall include prostitution, sexual exploitation, forced labour or services, slavery or practices similar to slavery, servitude or the removal of organs.

\section{Concept of Women Trafficking}

Trafficking in persons is an increasing problem that involves both sexual exploitation and labour exploitation of its victims. Trafficking affects all regions and majority of countries in the world. Both men and women may be victims of trafficking, but the primary victims are women and girls, the majority of whom are trafficked for the purpose of sexual exploitation. Traffickers usually target women because they are affected most by poverty and discrimination, which are the factors that impede their access to employment, educational opportunities and other resources.

These problem lead to creation of women's advocates in Central and Eastern Europe and the Common Wealth Independent States (CEE/CIS) and around the world to address the problem of women being trafficked into the commercial sex industry and labelled it as a human rights violation and form of gender based violence.

Trafficking in women is a complicated phenomenon with many forces as cause, perhaps the strongest factor is the desperate economic situation in the affected countries women may become victims when they sort assistance to obtain employment work permit, visas and other travel documents.

Some women are trafficked through formal or informal channels and some of them go knowing that they are going to work in the sex industry but without awareness of the terrible work conditions and violence that accompany the trafficking business; while some are forced into the business against their will. In most of the destination country, women are subjected to physical violence, sexual assault and rape, battery, imprisonment, threats and other forms of coercion.

\section{Situational Report in Human Trafficking in Nigeria}

The problem of human trafficking have been a general order of the day from all nooks and crannies of the nation as a result of object poverty, unemployment, illiteracy or selfish interest either by the parent of the victim or sometimes by their relations.

A recent study was conducted on behalf of International Labour Organization (ILO) in locations that were already suspected to have a high population of trafficked children (Edigbo, 2000). These were sited in Owerri, Port Harcourt, Calabar, Lagos, Kano, Sokoto and Maiduguri.

According to Kulu (2004), early in the year 2000, about 50 Nigerian citizens, mostly women, were also deported 
from Canada, America and Germany for illegal livelihood in these foreign countries.

According to the United Nations in Nigeria (2005), Nigerians were trafficked to Europe, the Middle East and other countries in Africa for the purpose of forced labour, domestic servitude, and sexual exploitation. Girls and women were trafficked to Italy, France, Spain, Netherland, Cote d'Voire and Benin. Children were trafficked for involuntary domestic and agricultural labour and street peddling within the country and to countries in west and central Africa. Both women and children were trafficked to Saudi Arabia.

Human trafficking in Nigeria follows different strategies with women and children being the victims. Boys were trafficked primarily to work as forced bondage labourers, street peddlers and beggars, while girls were trafficked for domestic services, street peddling and commercial sexual exploitation. Children in rural areas were trafficked to urban centers to work as domestics, street peddlers, merchant traders and beggars.

However, the Nigerian government is making effort to curtail the problem of trafficking in its domain. By employing the agencies in our borders like immigration service and others like NAPTIP.

\section{Objectives of Women Education}

United Nations Education Scientific and Cultural Organization (UNESCO) (1995) outlined the main objectives of women education as follows:

1. To enable women to improve their family's health and diet;

2. To increase women's productive ability thus raising the families standard of living;

3. To give women access to appropriate technologies and management of cooperatives;

4. To improve women's social and cultural states;

5. To enable women discharge their responsibilities more effectively;

6. To help women fight their own fears and feelings of inadequacy and inferiority;

7. To develop them in all round, that is, mentally, socially, physically, psychologically, religiously and economically;

8. To make women participate fully in all the affairs of their nation and to be the Centre of sustainable development;

9. To make women to acquire their own basic needs of the society like food, shelter, fuel, cloths and nourishing; and

10. To enhance national development and human development.

\section{Objectives of Education as Stated in the National Policy on Education}

Moreover, the National Policy on Education in Nigeria stated the objectives of education as follows:

1. A free and democratic society;

2. Just and egalitarian society;

3. A united, strong and self-reliant nation;

4. A great and dynamic economy;

5. A land of bright and full of opportunities for all citizens.

\section{Importance of Women Education}

Women are the backbone of the society, therefore, educating them will help improve the healthy living and discipline of the people of that society.

Eboh (1995) opines that the primary aim of women education is to prepare a woman for social, economic and above all, effective family care and maintenance of a happy home, which will lead to a stable family and society that promote national development. We can deduce that women education is non-self-centered, because women provide the first discipline at home. Therefore, educating women will lead to a disciplined society. Mohammed and One kata (1998) state that educating women folk is one of the steps forward in National development because men folk alone cannot successfully solve the problem of manpower shortage. The women should be given a special educational training in order to fully participate in the development of the nation. Moreover, it will not make them to look elsewhere for employment and become victims of trafficking.

King and Hill (1993), note that one of the main functions of education is to prepare young people for adult life. If the girl-child is provided with education at the right time, it shall broaden her horizon in which she will detect the ill of 
trafficking, not to talk of fallen victim.

Moreover, King and Hill (1993) go further to explain the importance of investing on women education as they are the custodian of younger generation who are going to be the leaders of tomorrow. Educating women will enable them to discharge their responsibilities more effectively; by educating their children on how to become good citizens and shine away from the ills of the society.

Education is the light and bedrock of any society. No nation develops above her education sector. Hence, Nigerian education system should gear towards self-sufficiency and entrepreneurship to make the citizens fend for themselves.

\section{Conclusion}

Human trafficking is a threat to human dignity and development of sense of self-worth. It inflicts physical torture and abuse on the victims and result to ill-health on earth and even death. It is also a direct blow on the human resources of a nation. On the other hand, education is a complex way of life if given to citizens; it will help to find solutions to problems that affect them. Women education should be promoted and geared towards social, economic, and above all, effective family care and maintenance of happy home, which will lead to a stable family and society at large. Therefore, all hands must be on deck to curb female trafficking, which is regarded to be the fastest growing branch of organized crime in the world.

\section{Recommendations}

In order to resolve the problem enumerated earlier and improve quality of citizens in this country, the following are considered as recommendations.

> Government should provide basic education especially for our women and children, and not only in literacy, but in vocational skills, in order to promote self-reliance and self-sufficiency.

$>$ Enlightenment campaigns should be mounted in the media and social media on the dangers of trafficking.

$>$ Doctors and health personnel should disseminate information on the effects of trafficking and prostitution through media programs.

$>$ Traditional and religious leaders need to put head together and fight the problem of human trafficking in our society; they must preach and also act as a model to their followers.

$>$ Parents should, as a matter of top priority, adequately socialize their children and assist them to acquire basic skills with which they can earn a living.

$>$ A collective and co-operative effort should be made by national and international governments to curb this problem.

\section{References}

Adamu(1996) Women Education for National Development. A Paper Presented at Annual National Conference of National Association of Curriculum Theorist (NACT) at Federal College of Education, Zaria P.11-15.

Adedokun, M.I. (2008) "causes and effects of women and child trafficking". Unpublished Research, Department of education, ABU zaria. Aliyu D. (2004) Women Education: Its problems and prospects, Kano Manifold pub com Ltd P 20.

Alele W. (1994).The Contribution of Women to National.Development Nigeria NAVWP P.81 Vol. 3 No. 2.

Eboh B.C (1995), Social-Cultural Barriers to Effective Participation of Women in Nigeria's Technology Development, Journal at Technical Education Review (4) 40.

Lazarus R.S (1996) Patterns of Adjustment and Human Effectiveness. Onaivi Pub Co Ltd Nigeria P. I-26.

King, M. and Hill, A.M (1985), Women's Education in Developing Countries. London: John Hopking University Press P. 66-67.

Kulu, L. (2004) "Human Trafficking and Child Labour" in July, 26.

UNESCO (1995); The Gender Dimension of Science and Technology-Extract from the World Science Report 1996, London; UNESCO P.25.

Surra, J.S.O (1997) Grander Capes U. Technology Education Raytel Co. Ltd P.103-105.

Ololobou Y.P.S (Ed) (2004) social Studies for Effective Citizenship: Kano: The Kano-Zaria Social Studies Collective.

UWO (2005) United Nation Organization Reports on Human Rights Practices in Nigeria. http/lgvnet.com/humantrafficking/niger.htm.

UNODC (2009) United Nation Office of Drug and Crime Report http://gvnet.com/human trafficking/nigeria.htm.

USA (2009), State Department Trafficking in Persons Report.http://gvnet.com/human trafficking/nigeria.htm. 